\title{
2-Selenouridine triphosphate synthesis and Se-RNA transcription
}

\author{
HUIYAN SUN, SIBO JIANG, JULIANNE CATON-WILLIAMS, HEHUA LIU, and ZHEN HUANG ${ }^{1}$ \\ Department of Chemistry, Georgia State University, Atlanta, Georgia 30303, USA
}

\begin{abstract}
2-Selenouridine $\left({ }^{\mathrm{Se}} \mathrm{U}\right)$ is one of the naturally occurring modifications of Se-tRNAs ( ${ }^{\mathrm{Se} U-R N A)}$ at the wobble position of the anticodon loop. Its role in the RNA-RNA interaction, especially during the mRNA decoding, is elusive. To assist the research exploration, herein we report the enzymatic synthesis of the ${ }^{\mathrm{Se}} \mathrm{U}-\mathrm{RNA}$ via 2-selenouridine triphosphate ( $\left.{ }^{\mathrm{Se}} \mathrm{UTP}\right)$ synthesis and RNA transcription. Moreover, we have demonstrated that the synthesized ${ }^{S e}$ UTP is stable and recognizable by T7 RNA polymerase. Under the optimized conditions, the transcription yield of Se U-RNA can reach up to $85 \%$ of the corresponding native RNA. Furthermore, the transcribed ${ }^{S e} \mathrm{U}$-hammerhead ribozyme has the similar activity as the corresponding native, which suggests usefulness of ${ }^{\mathrm{Se}} \mathrm{U}$-RNAs in function and structure studies of noncoding RNAs, including the Se-tRNAs.
\end{abstract}

Keywords: 2-selenouridine triphosphate; RNA transcription; RNA structure and function; hammerhead ribozyme; RNA crystallography

\section{INTRODUCTION}

RNA is involved in numerous biological processes, such as genetic storage, transcription, translation, and regulation (Watson 1963; Serganov and Patel 2007). Moreover, RNA can fold into well-defined three-dimensional structures to interact with proteins and catalyze biochemical reactions (Ponting et al. 2009; Schmeing and Ramakrishnan 2009). The appreciation for the uniqueness of RNAs, especially noncoding RNAs for their structure and function diversities, has increased extensively in the past decade. However, the functional understanding of these complicated macromolecules is often limited. The functional understanding of many natural modifications of the RNAs is even less. Thus, studying RNA natural modifications has become a very active research area in order to better understand biophysical and chemical properties of RNAs (such as tRNA and rRNA). So far, $>100$ RNA modifications have been discovered in nature (DuninHorkawicz et al. 2006), and many of them are frequently discovered in tRNA. 2-Selenouridine $\left({ }^{2-S e} \mathrm{U}\right.$ or $\left.{ }^{\mathrm{Se}} \mathrm{U}\right)$ is one of naturally occurring nucleosides and exists at the wobble position of the anticodon loop in various bacterial tRNAs (Escherichia coli, Methanococcus vanni-elii, Clostridium sticklandii, etc.) (Ching et al. 1985; Dunin-Horkawicz et al. 2006). This Semodification might play a critical role in the mRNA decoding process. It was hypothesized that the 2-Se-modification may

\footnotetext{
${ }^{1}$ Corresponding author

E-mail huang@gsu.edu

Article published online ahead of print. Article and publication date are at http://www.rnajournal.org/cgi/doi/10.1261/rna.038075.112.
}

enhance the accuracy and efficiency of protein translation (Lim and Curran 2001; Sun et al. 2012).

Moreover, another advantage of selenium modification in nucleic acid research is its assistance in addressing phase issue in X-ray crystallography via multiwavelength anomalous dispersion (MAD) or single-wavelength anomalous dispersion (SAD). Heavy atoms, such as selenium (Se) and bromine $(\mathrm{Br})$, are suitable as anomalous scattering centers, which have been extensively applied in protein and nucleic acid crystallography. Encouraged by the successful selenium-assisted MAD phasing (Hendrickson et al. 1990; Ferre-D'Amare et al. 1998), we have pioneered and established nucleic acid $\mathrm{X}$-ray crystallography with selenium derivatization (Carrasco et al. 2001; Caton-Williams and Huang 2008a; Sheng and Huang 2010; Lin et al. 2011b). Among the synthesized Se-derivatives, 2 -selenouridine is stable and the only one found in nature so far. Furthermore, the single oxygen atom substitution with selenium at the exo-2 position doesn't interfere with the hydrogen bonding in the Watson-Crick U/A base pair, thereby preserving the base-pairing function and structure (Sun et al. 2012). Therefore, the 2-selenouridine synthesis and its incorporation into RNAs may largely facilitate both structure and function investigations.

Generally, there are two strategies to synthesize the Sederivatized RNAs: solid-phase synthesis, and transcription. The first method offers the site-specific incorporation of the Se-nucleoside. However, it is limited to relatively short RNAs (up to $50 \mathrm{nt}$ ) for large-scale synthesis. In addition, it requires multiple steps in deprotection and purification. The 2selenouridine chemical incorporation into RNAs has been 


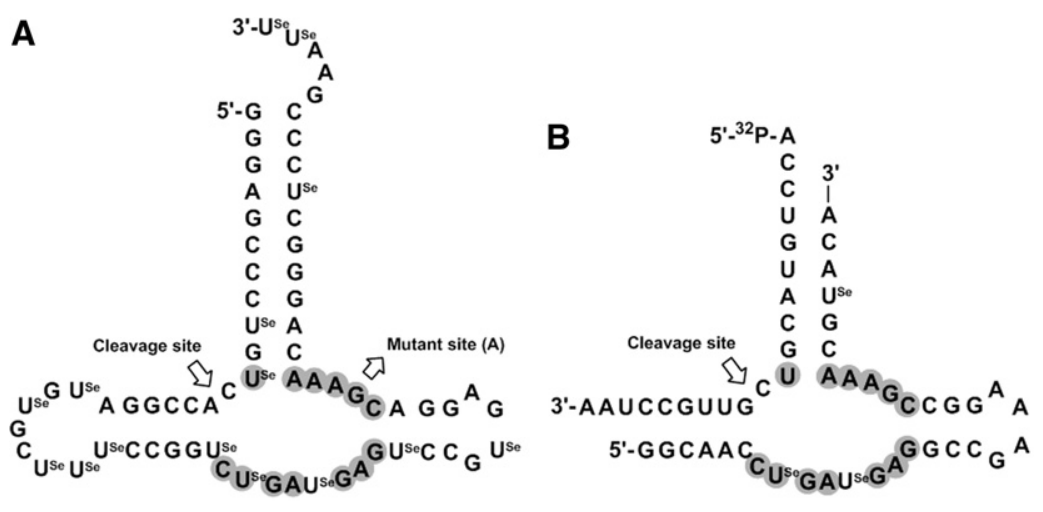

FIGURE 1. (A) Secondary structure of the self-cleaving ${ }^{\mathrm{Se}} \mathrm{U}$-hammerhead ribozymes, including the wild type (WHR) and crippled mutant (MHR). The mutant and cleavage sites are indicated by arrows. Highly conserved bases are highlighted in gray. (B) Secondary structure of the non-selfcleaving ${ }^{\mathrm{Se}} \mathrm{U}$-hammerhead ribozyme and its $5^{\prime}-{ }^{32} \mathrm{P}$-labeled RNA substrate.

achieved via solid-phase synthesis (Sun et al. 2012). Our biophysical studies have shown that the 2-Se-modification discriminates against a U/G mispair (wobble pair), while preserving the native U/A pair. This result indicates that ${ }^{\mathrm{Se}} \mathrm{U}$ can largely improve the RNA base-pairing specificity and the RNA-RNA interaction fidelity. This result has encouraged us to incorporate the Se-modification into RNA by in vitro transcription, in order to further investigate the function and structure of the ${ }^{\mathrm{Se}} \mathrm{U}$-RNAs, such as the ${ }^{\mathrm{Se}} \mathrm{U}$-containing tRNAs. This enzymatic method can allow synthesis of longer RNAs (>50 nt) in a large quantity (multiple milligrams). Multiple selenium atoms can also be conveniently incorporated into RNA under the mild conditions. As a matter of fact, the transcription strategy with T7 RNA polymerase is favored by most molecular and structural biologists. Herein, we report the first synthesis of 2-selenouridine triphosphate $\left({ }^{\mathrm{Se}} \mathrm{UTP}\right)$ and the enzymatic incorporation of ${ }^{\mathrm{Se}} \mathrm{UTP}$ into noncoding RNAs. The active and mutant hammerhead ribozymes (Fig. 1) were successfully transcribed and examined with ${ }^{\mathrm{Se}} \mathrm{UTP}$. The transcribed ${ }^{\mathrm{Se}} \mathrm{U}$-hammerhead ribozyme is active, suggesting that the ${ }^{\mathrm{Se}} \mathrm{U}$ RNAs are useful in both function and structure studies of noncoding RNAs.

\section{RESULTS AND DISCUSSION}

In order to minimize by-product formation, the Se-nucleobase modifications are normally protected during chemical synthesis (Salon et al. 2007, 2008; CatonWilliams and Huang 2008b; Hassan et al. 2010; Sun et al. 2012). Since the 2seleno-modification on uridine is naturally occurring, we decided to directly explore its compatibility with chemical synthesis. We were pleasantly surprised that 2-seleno-uridine, without protec- tion, can be directly converted to the corresponding triphosphate. Thus, the synthesis (Scheme 1) of ${ }^{\mathrm{Se}} \mathrm{UTP}$ (3) started from deprotection of the $5^{\prime}$-DMTr group of the Se-uridine derivative 1 (Sun et al. 2012) under an acidic condition. Then, 2-Se-uridine (2) was converted to ${ }^{\mathrm{Se}} \mathrm{UTP}$ (3) via a one-pot synthesis: sequential treatments with phosphorus oxychloride $\left(\mathrm{POCl}_{3}\right)$, pyrophosphate, and bicarbonate (Yoshikawa et al. 1967; Caton-Williams and Huang 2008b).

After the synthesis, crude ${ }^{\text {Se}} \mathrm{UTP}$ (3) was precipitated from the reaction mixture and then purified by reverse-phase high-performance liquid chromatography (RP-HPLC). Purified ${ }^{\mathrm{Se}} \mathrm{UTP}$ was characterized by MS, HPLC, UV, ${ }^{1} \mathrm{H}-$, ${ }^{13} \mathrm{C}-$, and ${ }^{31} \mathrm{P}-\mathrm{NMR}$. The profiles of HPLC and UV analyses are shown in Figure 2. Some characterization spectra are included in Supplemental Material (Supplemental Figs. S1S4). To examine the ${ }^{\mathrm{Se}} \mathrm{UTP}$ compatibility with RNA polymerase in transcription, the linearized plasmid templates for the wild-type hammerhead-ribozyme (WHR) and the crippled mutant hammerhead-ribozyme (MHR) were used (Fig. 1A) for the ${ }^{\mathrm{Se}} \mathrm{U}$-RNA transcription. As expected, ${ }^{\mathrm{Se}} \mathrm{UTP}$ was recognized by T7 RNA polymerase (Fig. 3). Moreover, the mutant ${ }^{\mathrm{Se}} \mathrm{U}$-ribozyme (69-nt; containing 15 selenium atoms) was prepared via RNA transcription, and the integrity of the ${ }^{\mathrm{Se}} \mathrm{U}$-ribozyme $\left({ }^{\mathrm{Se}} \mathrm{U}-\mathrm{MHR}\right)$ was confirmed by MS analysis (Fig. $3 \mathrm{C}$ ). Under standard transcription conditions, the time-course transcriptions of both the native and ${ }^{\mathrm{Se}} \mathrm{U}$-modified mutant ribozymes were performed using the mutant template (Fig. 3A). It was exciting to observe the incorporation of 15 selenium atoms into a RNA molecule by RNA transcription. To increase the ${ }^{\mathrm{Se}} \mathrm{U}$-RNA transcription yield, condition optimizations were carried out, such as $\mathrm{Mg}^{2+}$ concentration and buffer $\mathrm{pH}$ 

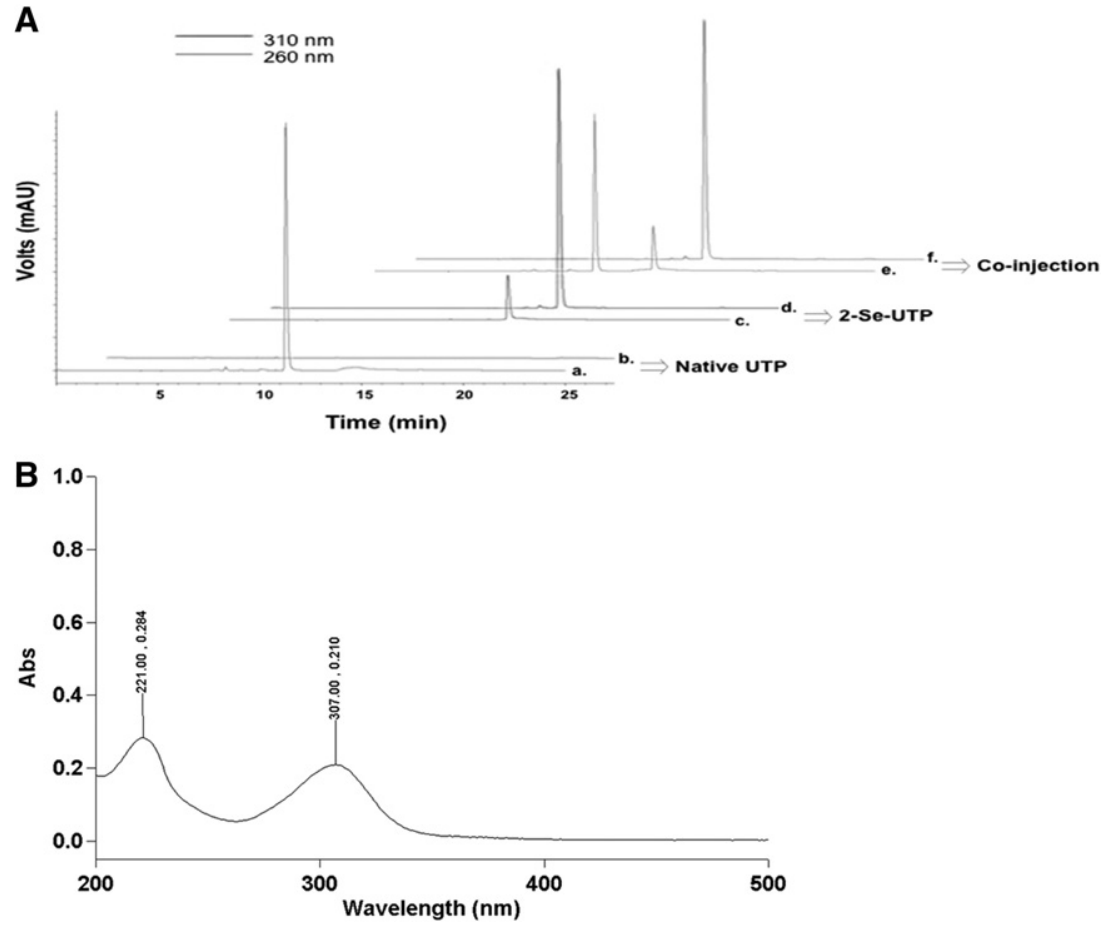

FIGURE 2. HPLC and UV analyses of ${ }^{\mathrm{Se}} \mathrm{UTP}$. (A) HPLC profiles: (a) native UTP monitored at $260 \mathrm{~nm}$ (retention time: $11.2 \mathrm{~min}$ ); (b) native UTP monitored at $307 \mathrm{~nm}$; (c) ${ }^{\mathrm{Se}} \mathrm{UTP}$ monitored at $260 \mathrm{~nm}$ (retention time: $14.1 \mathrm{~min}$ ); (d) ${ }^{\mathrm{Se}} \mathrm{UTP}$ monitored at $307 \mathrm{~nm}$ (retention time: $14.1 \mathrm{~min}$ ); (e) coinjection of both native UTP and ${ }^{\mathrm{Se}} \mathrm{UTP}$ monitored at $260 \mathrm{~nm}$ (retention time: $11.2 \mathrm{~min}$ and $14.1 \mathrm{~min}$ ); (f) coinjection of both native UTP and ${ }^{\mathrm{Se}} \mathrm{UTP}$ monitored at $307 \mathrm{~nm}$ (retention time: $14.1 \mathrm{~min})$. (B) UV spectrum of ${ }^{\mathrm{Se}} \mathrm{UTP}\left(\lambda_{\max }=307 \mathrm{~nm}\right)$. catalysis, a non-self-cleaving hammerhead ribozyme (35 nt in length) (Fig. 1B) was designed and transcribed with a double-stranded DNA (dsDNA) template ( $55 \mathrm{nt}$; dsDNA is more efficient in the SeRNA transcription than single-stranded DNA [ssDNA]). After transcription, the catalytic activity of the ${ }^{\mathrm{Se}} \mathrm{U}$-ribozyme was investigated by cleaving the $5^{\prime}-{ }^{32} \mathrm{P}$-labeled RNA substrate (20 nt) (Fig. 1B). The Seribozyme was examined and compared with the corresponding native ribozyme (Fig. 5). Our results indicated that the ${ }^{\mathrm{Se}} \mathrm{U}$-ribozyme is active, and its activity is similar to the native one.

\section{MATERIALS AND METHODS}

The synthesis of 2-selenouridine triphosphate was performed under argon, all solvents were redistilled, and all reagents were dried under reduced pressure prior to use. All native NTPs, the transcription buffer, and T7 RNA polymerase used in our transcription experiments were purchased from Epicentre. The templates of the wild-type and mutant hammerhead ribozymes were from the linearized plasmids (Lin et al. 2011a).
(Fig. 4; Supplemental Fig. S5). The optimized conditions are listed in Table 1. After the optimization, the ${ }^{\mathrm{Se}} \mathrm{U}-\mathrm{RNA}$ transcription can reach up to $85 \%$ yield of the corresponding native RNA (Fig. $3 B)$. This result suggested that ${ }^{\mathrm{Se}} \mathrm{UTP}$ does not cause significant disruption of the polymerase catalysis. Detailed experimental conditions are included in Materials and Methods.

To examine whether the ${ }^{\mathrm{Se}} \mathrm{U}$-hammerhead ribozyme (Fig. 1A) can cleave itself, we transcribed both the native and Se-modified wild-type self-cleaving ribozyme. The transcription reactions (Supplemental Fig. S6B) were carried out in the standard transcription buffer (containing $6 \mathrm{mM} \mathrm{MgCl} 2$ ). It was observed that the native ribozyme self-cleaved completely during transcription, while over $80 \%$ of the Se-modified ribozyme self-cleaved. When we used the transcription buffer containing $10 \mathrm{mM} \mathrm{Mg}^{2+}$, the ${ }^{\mathrm{Se}} \mathrm{U}$-ribozyme was self-cleaved completely. To further examine the ${ }^{\mathrm{Se}} \mathrm{U}$-ribozyme

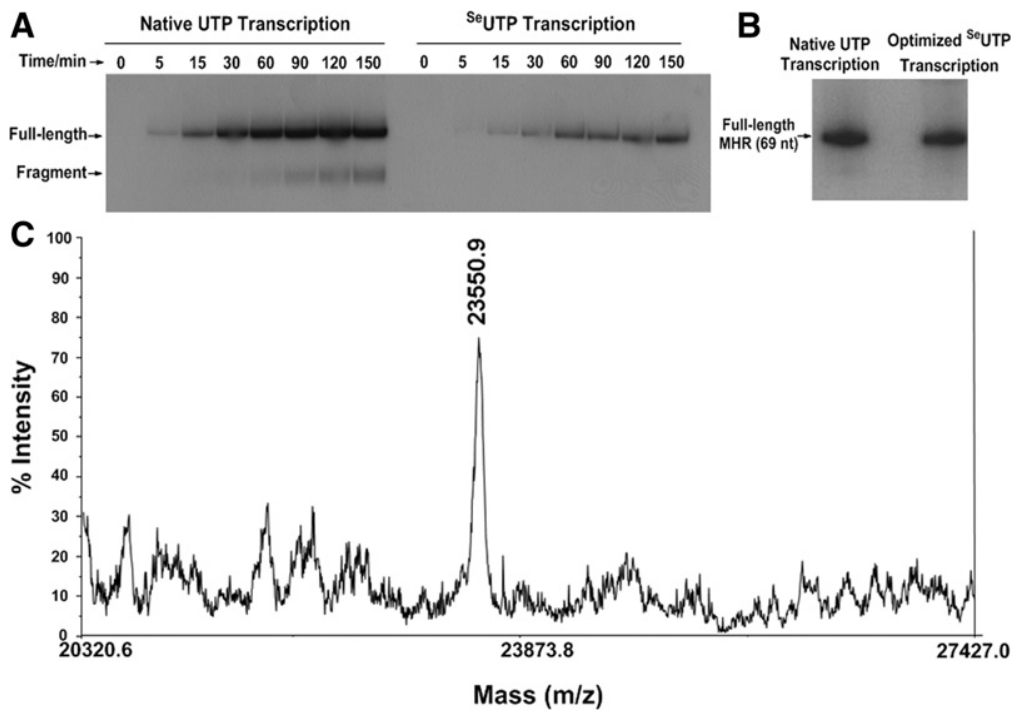

FIGURE 3. The ${ }^{\mathrm{Se}} \mathrm{U}$-ribozyme transcription with ${ }^{\mathrm{Se}} \mathrm{UTP}$ and T7 RNA polymerase. (A) The autoradiography gel image of in vitro transcription; (left) transcription of the native RNA (the crippled mutant hammerhead-ribozyme: MHR) with all native NTPs; the minor faster-moving band is the self-cleaved product (fragment); (right) transcription of the ${ }^{\mathrm{Se}} \mathrm{U}-\mathrm{MHR}$ with ${ }^{\mathrm{Se}} \mathrm{UTP}$ and other native NTPs. (B) Optimized Se-RNA transcription ( $\sim 85 \%$ yield compared to the corresponding native RNA transcription). Transcription conditions are listed in Table 1. (C) MALDI-TOF MS analysis of the ${ }^{\mathrm{Se}} \mathrm{U}-\mathrm{MHR}$ (molecular formula: $\mathrm{C}_{657} \mathrm{H}_{817} \mathrm{~N}_{264} \mathrm{O}_{476} \mathrm{P}_{71} \mathrm{Se}_{15}$ ); matrix: 3-hydroxypicolinic acid (3HPA, molecular formula: $\mathrm{C}_{6} \mathrm{H}_{5} \mathrm{NO}_{3}$ ); mass of ${ }^{\mathrm{Se}} \mathrm{U}-\mathrm{MHR}$ and matrix observed: 23,550.9 (calc. 23,551.4). 

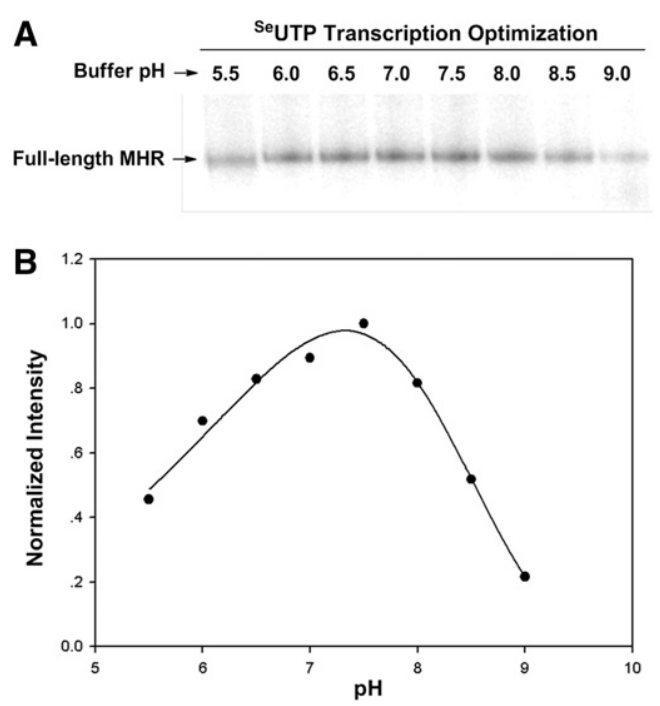

FIGURE 4. Experimental results of transcription optimizations with ${ }^{\mathrm{Se}} \mathrm{UTP}$. (A) Optimization of the transcription buffer $\mathrm{pH}(5.5-9.0)$. $\mathrm{pH}$ 7.5 is optimal for the Se-RNA transcription, while the $\mathrm{pH}$ of the standard transcription buffer is 7.9. (B) Data analysis of the $\mathrm{pH}$ optimization.

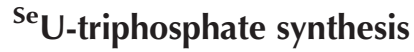

To 5'-DMTr-2-Se-uridine (Scheme 1, step 1, $305 \mathrm{mg}, 0.5 \mathrm{mmol}$ ) (Sun et al. 2012) dissolved in dichloromethane (5 mL), trifluoroacetic acid $(11 \mathrm{mg})$ was added. The solution was heated at $40^{\circ} \mathrm{C}$ for 30 min, followed by adding methanol $(0.2 \mathrm{~mL})$. The reaction was stirred vigorously for another $1 \mathrm{~h}$ to obtain a light yellow precipitate product (Scheme 1, step 2). The precipitate was recovered by centrifugation or filtration; the yield of step 2 was almost quantitative. 2Se-uridine (Scheme 1, step 2, $20 \mathrm{mg}$ ) was weighed and dried in a flask under high vacuum overnight, followed by injecting trimethyl phosphate $(0.4 \mathrm{~mL})$ to dissolve it and then stirring the flask in an ice bath. A solution of proton-sponge $(55 \mathrm{mg}, 2 \mathrm{eq})$ in trimethyl phosphate $(0.3 \mathrm{~mL})$ was injected into the solution of step 2 at $0^{\circ} \mathrm{C}$. After 3 min stirring, phosphorus oxychloride $\left(\mathrm{POCl}_{3} ; 9 \mu \mathrm{L}, 1.5 \mathrm{eq}\right)$ diluted in trimethyl phosphate $(90 \mu \mathrm{L})$ was dropwise added into the solution of step 2 at $0^{\circ} \mathrm{C}$. The reaction was completed in $1.5 \mathrm{~h}$ (monitored on TLC). Tributylammonium pyrophosphate (64 mg, 2 eq., dissolved in $0.2 \mathrm{~mL}$ tributylamine and $0.4 \mathrm{~mL} \mathrm{DMF}$ ) was then quickly injected into the reaction. After vigorously stirring for 5 min, the reaction was quenched with triethylammonium bicarbonate $(1 \mathrm{M}, 3 \mathrm{~mL})$ and stirred for another $1 \mathrm{~h}$ at the room temperature to obtain compound 3. To the reaction solution, $\mathrm{NaCl}(3 \mathrm{M} \mathrm{NaCl}$, $0.5 \mathrm{~mL}$ ) was added, followed by adding ethanol $(14.5 \mathrm{~mL})$ and freezing the suspension at $-80^{\circ} \mathrm{C}$ for $1 \mathrm{~h}$ to precipitate the crude product. Compound 3 was recovered by centrifugation for $25 \mathrm{~min}$ at 14,000 rpm. The pellet was redissolved in water and analyzed by HPLC. ${ }^{\mathrm{Se}} \mathrm{UTP}$ ( step 3) was purified by HPLC. The identity of ${ }^{\mathrm{Se}} \mathrm{UTP}$ as a triethylammonium salt was confirmed by NMR $\left({ }^{1} \mathrm{H}-,{ }^{13} \mathrm{C}-\right.$, and ${ }^{31} \mathrm{P}-$ NMR) and mass analyses. ${ }^{1} \mathrm{H}-\mathrm{NMR}\left(400 \mathrm{MHz} ; \mathrm{D}_{2} \mathrm{O}\right) \delta: 8.22(\mathrm{~d}$, $J=8.1 \mathrm{~Hz}, 1 \mathrm{H}, \mathrm{H}-6), 6.79\left(\mathrm{~d}, J=3.0 \mathrm{~Hz}, 1 \mathrm{H}, \mathrm{H}-1^{\prime}\right), 6.38$ (d, $J=8.1$ $\mathrm{Hz}, 1 \mathrm{H}, \mathrm{H}-5), 4.54-4.33$ (m, 5H, H-2', $\left.3^{\prime}, 4^{\prime}, 5^{\prime}\right), 3.21$ (d, $J=7.3 \mathrm{~Hz}$, $\mathrm{CH}_{2}$ of triethylammonium), $1.28\left(\mathrm{t}, J=7.3 \mathrm{~Hz}, \mathrm{CH}_{3}\right.$ of triethylammonium). ${ }^{13} \mathrm{C}-\mathrm{NMR}\left(100 \mathrm{MHz} ; \mathrm{D}_{2} \mathrm{O}\right) \delta: 174.7$ (s, C-4), 161.7 (s, C-2), 140.9 (s, C-6), 107.6 (s, C-5), 94.6 (s, C-1' ), 82.2 (d, J=9.1 Hz, C-4'), 74.0 (s, C-2'), 67.3 (s, C-3'), 62.9 (d, J=5.1 Hz, C-5'),
45.6 (s, $\mathrm{CH}_{2}$ of triethylammonium), $7.2\left(\mathrm{~s}, \mathrm{CH}_{3}\right.$ of triethylammonium). ${ }^{31} \mathrm{P}-\mathrm{NMR}\left(162 \mathrm{MHz} ; \mathrm{D}_{2} \mathrm{O}\right) \delta:-7.4(\mathrm{~d}, J=19.7 \mathrm{~Hz}, \alpha-\mathrm{P})$, $-11.3(\mathrm{~d}, J=19.6 \mathrm{~Hz}, \gamma-\mathrm{P}),-22.1$ (t, $J=19.6 \mathrm{~Hz}, \beta-\mathrm{P})$. HRMS

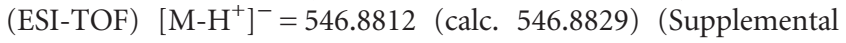
Material; Supplemental Figs. S1-S4).

\section{HPLC and UV analyses of ${ }^{\text {Se UTP }}$}

The maximal UV absorbance of native uridine triphosphate is 260 $\mathrm{nm}$, while that of the ${ }^{\mathrm{Se}} \mathrm{U}$-triphosphate is $307 \mathrm{~nm}$. In the HPLC analysis, both the native and selenium-modified UTPs were monitored under two wavelengths (260 and $307 \mathrm{~nm}$ ). The synthesized ${ }^{\mathrm{Se}} \mathrm{UTP}$ was purified by HPLC (Ultimate XB-C18, $250 \mathrm{~mm} \times 21.2 \mathrm{~mm}$, $10 \mu \mathrm{m})$ with a gradient of $100 \%$ buffer A $(20 \mathrm{mM}$ triethylammonium acetate in water) to $25 \%$ buffer B (20 mM triethylammonium acetate in 50\% acetonitrile and 50\% water) for $20 \mathrm{~min}$. The HPLC analysis was performed (Ultimate XB-C18, $250 \mathrm{~mm} \times 4.6 \mathrm{~mm}, 5 \mu \mathrm{m}$ ) with a gradient from $100 \%$ buffer $\mathrm{A}(20 \mathrm{mM}$ triethylammonium acetate in water) to $40 \%$ buffer B (20 mM triethylammonium acetate in $50 \%$ acetonitrile and 50\% water) for $15 \mathrm{~min}$. The HPLC and UV profiles are shown in Figure 2. The retention times of the native UTP and ${ }^{\mathrm{Se}} \mathrm{UTP}$ were 11.2 and $14.1 \mathrm{~min}$, respectively.

\section{Transcription of the RNAs with native NTPs}

The native RNAs were transcribed with the transcription protocol (final concentration) in RNA polymerase buffer ( $40 \mathrm{mM}$ Tris- $\mathrm{HCl}$, $6 \mathrm{mM} \mathrm{MgCl}_{2}, 2 \mathrm{mM}$ spermidine, pH 7.9), DTT (10 mM), ATP, UTP, CTP, and GTP (0.5 mM each NTP), DNA template (nonself-cleaving hammerhead ribozyme: $1 \mu \mathrm{M}$ dsDNA template [55 $\mathrm{nt}$ ]; self-cleaving hammerhead ribozyme [mutant and wild-type]: $50 \mathrm{ng} / \mu \mathrm{L}$ linearized plasmid), T7 RNA polymerase (2 units $/ \mu \mathrm{L}$, Epicentre), and RNase-free water to adjust to the final volume (e.g., $20 \mu \mathrm{L})$. The transcription reaction was incubated for $1 \mathrm{~h}$ at $37^{\circ} \mathrm{C}$.

\section{Transcription and analysis of the Se-RNAs}

The transcription experiment was carried out by following the standard procedures from the manufacturer, Epicentre (AmpliScribe T7Flash Transcription Kit). $\alpha-{ }^{32} \mathrm{P}$-ATP was used as the radioactive labeling material for transcription experiments. Each transcription reaction $(5 \mu \mathrm{L})$ contained ATP, CTP, GTP, and UTP or ${ }^{\mathrm{Se}} \mathrm{UTP}(0.5 \mathrm{mM}$ each), linearized plasmid DNA template $(50 \mathrm{ng} / \mu \mathrm{L})$, DTT (10 $\mathrm{mM})$, transcription buffer $(1 \times)$ for T7 RNA polymerase, T7 RNA polymerase (10-20 units), and RNase-free water. In the time-course experiments, a gel-loading dye $(5 \mu \mathrm{L})$ containing $100 \mathrm{mM}$ EDTA was used to quench the reaction at each time point, followed by denaturing PAGE $(15 \% \mathrm{gel})$ analysis and autoradiography. The translated

TABLE 1. Optimized conditions for the Se-RNA transcription

\begin{tabular}{lccccc}
\hline & $\mathrm{pH}$ & $\mathrm{Mg}^{2+}$ & UTP conc. & T7 pol. & Trans. time \\
\hline $\begin{array}{c}\text { Native } \\
\begin{array}{c}\text { condition } \\
\text { Se-modified } \\
\text { condition }\end{array}\end{array}$ & 7.9 & $6 \mathrm{mM}$ & $0.5 \mathrm{mM}$ & 10 units & $1 \mathrm{~h}$ \\
\hline
\end{tabular}



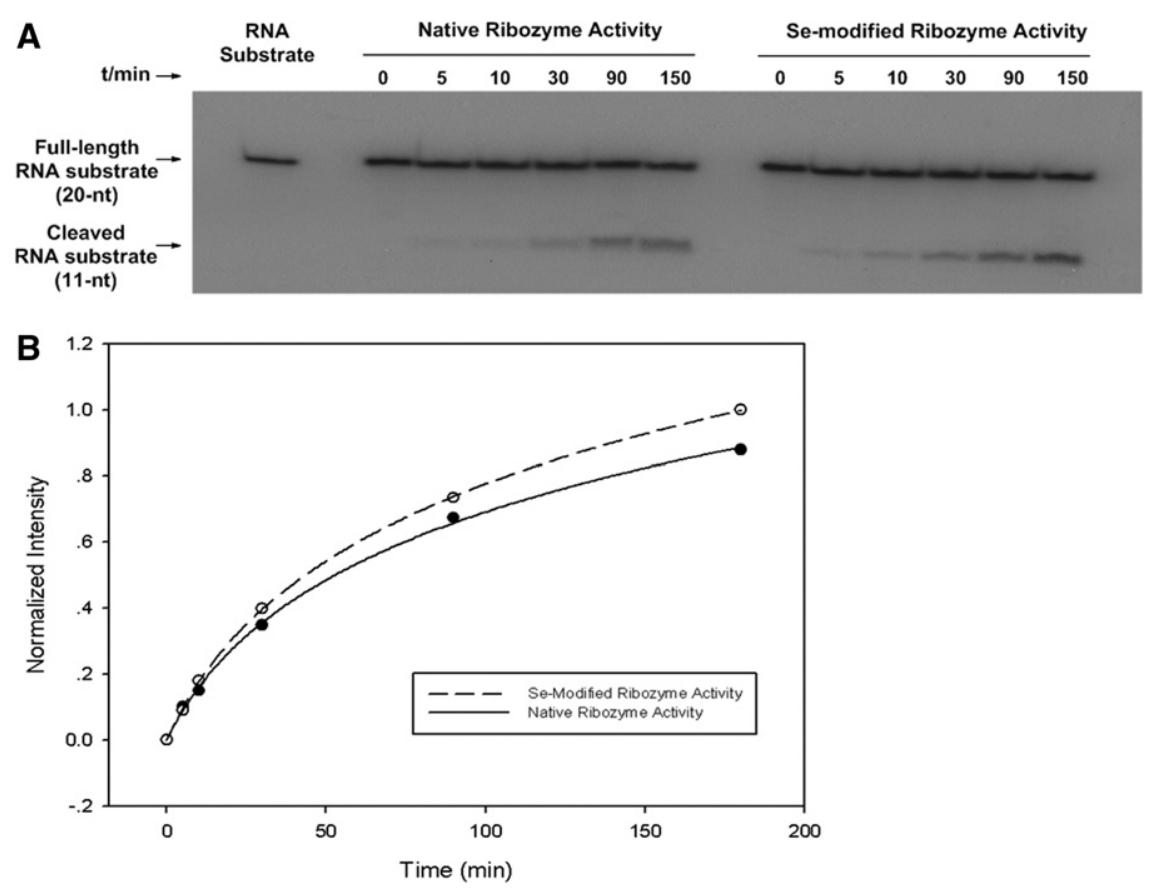

FIGURE 5. The catalytic activity of the Se-modified ribozyme. (A) The time-course experiment of the $5^{\prime}{ }^{32} \mathrm{P}$-RNA substrate digested with the non-self-cleaving native and Se-modified hammerhead ribozymes under the same conditions. The experiment was carried out at room temperature, with $10 \mathrm{mM} \mathrm{Mg}^{2+}$, in the ribozyme buffer. (B) Plot of the ${ }^{\mathrm{Se}} \mathrm{U}$-ribozyme catalysis (dashed line) compared with the corresponding native (solid line). The cleavages of the RNA substrate by the native and Se-modified ribozymes ( $y$-axis) were normalized via comparison to the substrate cleavage by the native ribozyme at $150 \mathrm{~min}$ (defined as 1.0).

RNAs were WHR and MHR (Fig. 1). The transcribed mutant Sehammerhead ribozyme with incorporated 15 selenium atoms was confirmed by MALDI-TOF MS analysis (Fig. 3C).

The Se-RNAs were transcribed with the transcription protocol (final concentration) in RNA polymerase buffer (40 mM Tris- $\mathrm{HCl}, 12$ $\mathrm{mM} \mathrm{MgCl}_{2}, 2 \mathrm{mM}$ spermidine, pH 7.5), DTT (10 mM), ATP, ${ }^{\mathrm{Se} U T P}$, CTP, and GTP (0.5 mM each NTP), DNA template [non-self-cleaving hammerhead ribozyme: $1 \mu \mathrm{M}$ dsDNA template $(55 \mathrm{nt})$; selfcleaving hammerhead ribozyme (mutant and wild-type): $50 \mathrm{ng} / \mu \mathrm{L}$ linearized plasmid], T7 RNA polymerase (4 units/ $\mu \mathrm{L}$, Epicentre), and RNase-free water to adjust to final volume (e.g., $20 \mu \mathrm{L}$ ). The transcription reaction was incubated for $3 \mathrm{~h}$ at $37^{\circ} \mathrm{C}$.

\section{Catalytic activity analysis of the Se-RNAs}

The non-self-cleaving hammerhead ribozyme (5'-GGCA-ACCUGA UGAGGCCGAAAGGCCGAAACGUACA-3') (Fig. 1B) for the catalytic experiments was transcribed following the standard procedures described above. The DNA template used for this transcription was a 55-nt dsDNA (5'-TGTACGTTTCGGCCTTTCGGCCTCATCAGG TTGCCTATAGTGAGTCGTATTACGC- $3^{\prime}$ and its complementary sequence). After the transcription, the native and Se-modified ribozymes were purified and adjusted to the same concentration (monitored by UV). The RNA substrate (20 nt, 5'-ACCUGUACGUCG UUGCCUAA- $3^{\prime}$ ) (Fig. 1B) chemically synthesized by solid-phase synthesis was kinased with $\gamma^{-}{ }^{32} \mathrm{P}$-ATP at the $5^{\prime}$ end for the ribozyme digestion. The digestion was performed in the buffer $(10 \mathrm{mM}$ Tris- $\mathrm{HCl}, 10 \mathrm{mM} \mathrm{MgCl}_{2}, \mathrm{pH}$ 7.6) and with $5^{\prime}-{ }^{32} \mathrm{P}$-labeled RNA substrate (final concentration: $50 \mu \mathrm{M}$ ) at $27^{\circ}$ C. Aliquots $(10 \mu \mathrm{L}$ each) were taken at the time intervals $(0,5,10,30,90$, and $150 \mathrm{~min})$, and each was mixed with EDTA $(5 \mu \mathrm{L}, 50$ $\mathrm{mM}$ ) dissolved in a saturated urea solution (aqueous) to quench the digestion. The $5^{\prime}$-labeled RNA substrate was digested to the 9-nt fragment and the $5^{\prime}-{ }^{32} \mathrm{P}$-RNA fragment (11 nt). The ${ }^{32}$ P-labeled RNA allowed monitoring the substrate digestion via gel electrophoresis and autoradiography. The time-course results of the ribozyme digestion are shown in Figure 5 and Supplemental Fig. S6A.

\section{Optimization of ${ }^{\mathrm{Se}} \mathrm{U}$-RNA transcription}

To maximize the transcription yield, condition optimizations have been performed. The linearized plasmid of the mutant hammerhead ribozyme (Fig. 1A) was used as the template, which incorporates $15^{\mathrm{Se}}$ Us into the ribozyme. The transcription buffers with various $\mathrm{pH}$ values were first examined, since the acidity of the imino group (3-NH) of ${ }^{\mathrm{Se}} \mathrm{U}$ is higher than that of the native $\mathrm{U}$ (Sun et al. 2012). The $\mathrm{pH}$ values of the transcription buffer $(40 \mathrm{mM}$ Tris base or sodium phosphate, $6 \mathrm{mM} \mathrm{MgCl}_{2}, 2 \mathrm{mM}$ spermidine, and $10 \mathrm{mM}$ DTT) were adjusted. The Se-RNA transcription was examined under eight $\mathrm{pH}$ values $(\mathrm{pH} 5.5,6.0,6.5,7.0,7.5$, 8.0, 8.5, and 9.0) and indicated that $\mathrm{pH} 7.5$ was optimal for the Se-RNA transcription (Fig. 4). The $\mathrm{pH}$ of the standard transcription buffer is 7.9. $\mathrm{Mg}^{2+}$ concentration in the transcription buffer was also examined by varying it from 4 to $12 \mathrm{mM}$. As the increased $\mathrm{MgCl}_{2}$ concentration yielded higher transcription yield (Supplemental Fig. $\mathrm{S} 5 \mathrm{~A}), 12 \mathrm{mM} \mathrm{MgCl}_{2}$ was chosen for the Se-RNA transcription. Other components, such as spermidine (from 2-8 mM) and ${ }^{\mathrm{Se}} \mathrm{UTP}$ (from 0.5 to $1.5 \mathrm{mM}$ ), were also examined for the transcription optimization. However, we found that increases of the concentrations of these components slightly decreased the transcription yield (Supplemental Fig. S5B). Moreover, a higher quantity of T7 RNA polymerase can increase the Se-RNA transcription yield (Supplemental Fig. S5C). Finally, after combining these optimized conditions (Table 1 ), we could increase the yield of the ${ }^{\mathrm{Se}} \mathrm{U}$-RNA transcription up to $85 \%$ of the corresponding native RNA (Fig. $3 \mathrm{~B}$ ), and these conditions have been used to transcribe various ${ }^{\mathrm{Se}} \mathrm{U}$-RNAs.

\section{Thermostability of the ${ }^{\text {Se U-RNA }}$}

To examine the thermostability of the ${ }^{\mathrm{Se}} \mathrm{U}-\mathrm{RNA}$, we designed a short Se-RNA (trimer: $5^{\prime}-\mathrm{U}^{\mathrm{Se}} \mathrm{UU}-3^{\prime}$ ) for this study. This Se-RNA was chemically synthesized by solid-phase synthesis and purified (Sun et al. 2012). We heated the Se-RNA continually at $70^{\circ} \mathrm{C}$ for a few hours and monitored it by HPLC at both 260 and $307 \mathrm{~nm}$, since the 2-selenium modification has a unique UV-absorption at 307 $\mathrm{nm}$, while the native nucleotides absorb strongly at $260 \mathrm{~nm}$. The HPLC analysis was performed (Ultimate XB-C18, $250 \mathrm{~mm} \times 4.6$ $\mathrm{mm}, 5 \mu \mathrm{m})$ with a gradient from $100 \%$ buffer A $(20 \mathrm{mM}$ 


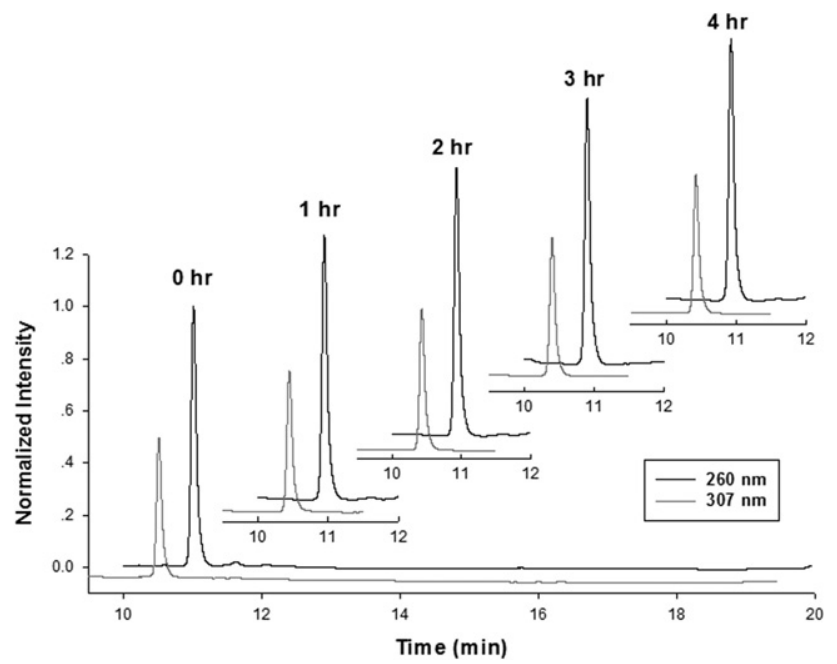

FIGURE 6. Thermostability study of ${ }^{\mathrm{Se}} \mathrm{U}-\mathrm{RNA} \cdot 5^{\prime}-\mathrm{U}^{\mathrm{Se}} \mathrm{UU}-3^{\prime}$ was heated at $70^{\circ} \mathrm{C}$ for several hours. HPLC was monitored at both 260 and 307 $\mathrm{nm}$ (retention time: $10.9 \mathrm{~min}$ ).

triethylammonium acetate in water) to $40 \%$ buffer B (20 mM triethylammonium acetate in 50\% acetonitrile and 50\% water) for 15 min. No significant decomposition was observed over 4-h heating at $70^{\circ} \mathrm{C}$ (Fig. 6), indicating that this Se-modification is relatively stable.

\section{SUPPLEMENTAL MATERIAL}

Supplemental material is available for this article.

\section{ACKNOWLEDGMENTS}

This work was financially supported by NIH (R01GM095881) and the Georgia Cancer Coalition (GCC) Distinguished Cancer Clinicians and Scientists.

Received December 27, 2012; accepted June 6, 2013.

\section{REFERENCES}

Carrasco N, Ginsburg D, Du Q, Huang Z. 2001. Synthesis of seleniumderivatized nucleosides and oligonucleotides for X-ray crystallography. Nucleosides Nucleotides Nucleic Acids 20: 1723-1734.

Caton-Williams J, Huang Z. 2008a. Biochemistry of selenium-derivatized naturally occurring and unnatural nucleic acids. Chem Biodivers 5: 396-407.
Caton-Williams J, Huang Z. 2008b. Synthesis and DNA-polymerase incorporation of colored 4-selenothymidine triphosphate for polymerase recognition and DNA visualization. Angew Chem Int Ed Engl 120: 1747-1749.

Ching WM, Alzner-DeWeerd B, Stadtman TC. 1985. A seleniumcontaining nucleoside at the first position of the anticodon in seleno-tRNA ${ }^{\text {Glu }}$ from Clostridium sticklandii. Proc Natl Acad Sci 82: 347-350.

Dunin-Horkawicz S, Czerwoniec A, Gajda MJ, Feder M, Grosjean H, Bujnicki JM. 2006. MODOMICS: A database of RNA modification pathways. Nucleic Acids Res 34: D145-D149.

Ferre-D'Amare AR, Zhou K, Doudna JA. 1998. Crystal structure of a hepatitis $\delta$ virus ribozyme. Nature 395: 567-574.

Hassan AE, Sheng J, Zhang W, Huang Z. 2010. High fidelity of base pairing by 2-selenothymidine in DNA. J Am Chem Soc 132: 21202121.

Hendrickson WA, Horton JR, LeMaster DM. 1990. Selenomethionyl proteins produced for analysis by multiwavelength anomalous diffraction (MAD): A vehicle for direct determination of three-dimensional structure. EMBO J 9: 1665-1672.

Lim VI, Curran JF. 2001. Analysis of codon: Anticodon interactions within the ribosome provides new insights into codon reading and the genetic code structure. RNA 7: 942-957.

Lin L, Caton-Williams J, Kaur M, Patino AM, Sheng J, Punetha J, Huang Z. 2011a. Facile synthesis of nucleoside 5' -(a-P-seleno)-triphosphates and phosphoroselenoate RNA transcription. RNA 17: 1932-1938.

Lin L, Sheng J, Huang Z. 2011b. Nucleic acid X-ray crystallography via direct selenium derivatization. Chem Soc Rev 40: 45914602.

Ponting CP, Oliver PL, Reik W. 2009. Evolution and functions of long noncoding RNAs. Cell 136: 629-641.

Salon J, Sheng J, Jiang J, Chen G, Caton-Williams J, Huang Z. 2007. Oxygen replacement with selenium at the thymidine 4-position for the Se base pairing and crystal structure studies. J Am Chem Soc 129: 4862-4863.

Salon J, Jiang J, Sheng J, Gerlits OO, Huang Z. 2008. Derivatization of DNAs with selenium at 6-position of guanine for function and crystal structure studies. Nucleic Acids Res 36: 7009-7018.

Schmeing TM, Ramakrishnan V. 2009. What recent ribosome structures have revealed about the mechanism of translation. Nature 461: 12341242.

Serganov A, Patel DJ. 2007. Ribozymes, riboswitches and beyond: Regulation of gene expression without proteins. Nat Rev Genet 8: 776-790.

Sheng J, Huang Z. 2010. Selenium derivatization of nucleic acids for $\mathrm{X}$-ray crystal-structure and function studies. Chem Biodivers 7: 753-785.

Sun H, Sheng J, Hassan AEA, Jiang S, Gan J, Huang Z. 2012. Novel RNA base pair with higher specificity using single selenium atom. Nucleic Acids Res 40: 5171-5179.

Watson JD. 1963. Involvement of RNA in the synthesis of proteins. Science 140: 17-26.

Yoshikawa M, Kato T, Takenishi T. 1967. A novel method for phosphorylation of nucleosides to $5^{\prime}$-nucleotides. Tetrahedron Lett 50: 50655068 . 

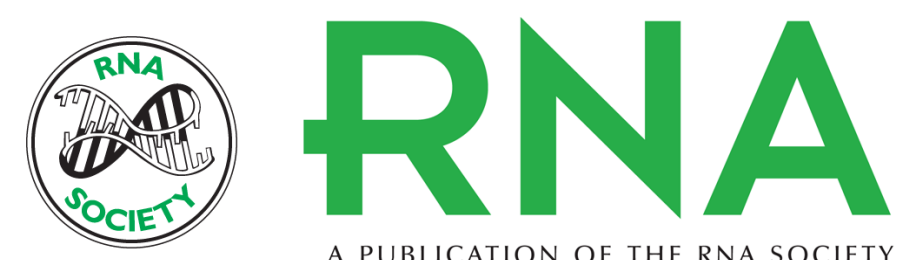

A PUBLICATION OF THE RNA SOCIETY

\section{2-Selenouridine triphosphate synthesis and Se-RNA transcription}

Huiyan Sun, Sibo Jiang, Julianne Caton-Williams, et al.

RNA 2013 19: 1309-1314 originally published online July 25, 2013

Access the most recent version at doi:10.1261/rna.038075.112

Supplemental Material

References

Creative Commons License

Email Alerting Service
http://rnajournal.cshlp.org/content/suppl/2013/07/18/rna.038075.112.DC1

This article cites 20 articles, 4 of which can be accessed free at: http://rnajournal.cshlp.org/content/19/9/1309.full.html\#ref-list-1

This article is distributed exclusively by the RNA Society for the first 12 months after the full-issue publication date (see http://rnajournal.cshlp.org/site/misc/terms.xhtml). After 12 months, it is available under a Creative Commons License (Attribution-NonCommercial 3.0 Unported), as described at http://creativecommons.org/licenses/by-nc/3.0/.

Receive free email alerts when new articles cite this article - sign up in the box at the top right corner of the article or click here.

To subscribe to $R N A$ go to:

http://rnajournal.cshlp.org/subscriptions 